\title{
Dietzia psychralcaliphila sp. nov., a novel, facultatively psychrophilic alkaliphile that grows on hydrocarbons
}

\footnotetext{
${ }^{1}$ Research Institute of Biological Resources, National Institute of Advanced Industrial Science and Technology, 2-17-2-1 TsukisamuHigashi, Toyohira-ku, Sapporo 062-8517, Japan

2 Department of Bioscience and Technology, School of Engineering, Hokkaido Tokai University, Minaminosawa, Minamiku, Sapporo 005-8601, Japan

3 Laboratory of Electron Microscopy, School of Dentistry, Hokkaido University, Kita-ku, Sapporo 060-8586, Japan
}

\author{
Isao Yumoto, ${ }^{1}$ Akio Nakamura, ${ }^{1,2}$ Hideaki Iwata, ${ }^{1,2}$ Kiyoshi Kojima, ${ }^{1,2}$ \\ Keita Kusumoto, ${ }^{1,2}$ Yoshinobu Nodasaka ${ }^{3}$ and Hidetoshi Matsuyama ${ }^{2}$
}

Author for correspondence: Isao Yumoto. Tel: +81 11 8578925. Fax: +81 118578900. e-mail: i.yumoto@aist.go.jp

\begin{abstract}
A novel, facultatively psychrophilic alkaliphile that grows on a chemically defined medium containing $n$-alkanes as the sole carbon source was isolated from a drain of a fish product-processing plant. The isolate was an aerobic, non-motile, Gram-positive bacterium. The bacterium was catalase-positive and oxidase-negative. The cell wall contained meso-diaminopimelic acid, arabinose and galactose; the glycan moiety of the cell wall contained acetyl residues. The G+C content of the DNA was $69 \cdot 6 \mathrm{~mol} \%$. Phylogenetic analysis based on $16 \mathrm{~S}$ rRNA gene sequences showed that the isolate was closely related to members of the genus Dietzia (96.1-96.8\% similarity). Comparisons of phenotypic and chemotaxonomic characteristics between the isolate and the two known Dietzia species showed that they were very similar. However, the isolate differed from the two known Dietzia species in growth temperature range and certain physiological characteristics. DNA-DNA hybridization revealed that the isolate had 38.4 and $\mathbf{4 9 . 7 \%}$ relatedness, respectively, to Dietzia maris and Dietzia natronolimnaea. On the basis of the physiological and biochemical characteristics, the phylogenetic position as determined by 16S rRNA gene analysis and DNA-DNA relatedness, it is concluded that the isolate should be designated as a novel species, for which the name Dietzia psychralcaliphila sp. nov. is proposed. The type strain is ILA-1 ${ }^{\top}\left(=J C M 10987^{\top}=\right.$ IAM $14896^{\top}=$ NCIMB $^{2}$ 13777').
\end{abstract}

Keywords: Dietzia psychralcaliphila, facultatively psychrophilic, alkaliphilic, $n$ alkanes, 16S rRNA phylogeny

\section{INTRODUCTION}

In the light of the growing concern over the Earth's environmental problems, bioremediation using microorganisms shows great promise. Oil pollution of the soil or water is widespread. Once an oil spill occurs, it has a great negative impact on the entire surrounding area. To date, there have been few examples of bioremediation of oil-contaminated soils and water under psychrophilic conditions compared with examples under mesophilic conditions. Although degradation of oil is difficult at moderate temperatures, it is even more difficult at low temperatures. At low temperatures, the viscosity of oil increases, preventing

The GenBank/EMBL/DDBJ accession number for the $16 \mathrm{~S}$ rRNA gene sequence of strain ILA-1 ${ }^{\top}$ is $A B 049630$. the spread of the oil in soil and water. In addition, low temperatures prevent the volatilization of short-chain alkanes (less than $\mathrm{C}_{10}$ ), thus increasing their solubility in the aqueous phase and their toxicity, which can delay microbial degradation. Long-chain alkanes are in a solid state at low temperatures. They can also delay the microbial degradation of oil. Cold-adapted micro-organisms capable of degrading oil hydrocarbons at low temperatures have been reported (Westlake et al., 1978; Whyte et al., 1996, 1998, 1999; MacCormack \& Fraile, 1997; Margesin \& Schinner, 1997a, b, c, 1999; Foght et al., 1999). However, few cold-adapted micro-organisms capable of degrading oil hydrocarbons have been identified to the species level to date.

In the present study, we isolated a cold-adapted alkaliphilic micro-organism that utilizes petroleum 
hydrocarbons over a wide $\mathrm{pH}$ range. We performed phenotypic characterization and phylogenetic analysis based on 16S rRNA gene sequences and found that the strain should be classified as a novel species belonging to the genus Dietzia. To the best of our knowledge, the isolate is the first reported facultatively psychrophilic alkaliphile that grows on a chemically defined medium containing $n$-alkanes as the sole carbon source.

\section{METHODS}

Bacterial strains and cultivation. A bacterial strain was isolated from water $\left(6^{\circ} \mathrm{C}, \mathrm{pH} 7\right)$ obtained from a drain pool of a fish-egg-processing plant using a synthetic medium (AT medium) that consisted of $5 \mathrm{~g} \mathrm{KNO}_{3}, 0.5 \mathrm{~g} \mathrm{KH}_{2} \mathrm{PO}_{4}, 0.5 \mathrm{~g}$ $\mathrm{MgSO}_{4} \cdot 7 \mathrm{H}_{2} \mathrm{O}, 0.01 \mathrm{~g} \mathrm{FeSO}_{4} .7 \mathrm{H}_{2} \mathrm{O}, 0.02 \mathrm{~g} \mathrm{CaCl} \mathrm{Cl}_{2} \cdot 2 \mathrm{H}_{2} \mathrm{O}$, $0.001 \mathrm{~g} \mathrm{MnSO}_{4} \cdot n \mathrm{H}_{2} \mathrm{O}, 0.0005 \mathrm{~g} \mathrm{ZnSO}_{4} .7 \mathrm{H}_{2} \mathrm{O}$ and $15 \mathrm{~g}$ agar in $11100 \mathrm{mM} \mathrm{NaHCO} / \mathrm{Na}_{2} \mathrm{CO}_{3}$ buffer $(\mathrm{pH} 10)$ in deionized water, supplemented with vaporized $n$-tetradecane as the sole carbon source. $n$-Tetradecane was vaporized onto the surface of the agar plate by inverting the plate over a piece of filtration paper that had been soaked in $n$-tetradecane. After 1 month of aerobic incubation at $4{ }^{\circ} \mathrm{C}$, strain ILA- $1^{\mathrm{T}}$ was isolated. In addition to this isolate, Dietzia maris JCM $6166^{\mathrm{T}}$ and Dietzia natronolimnaea (originally named 'Dietzia natronolimnaios') $15 \mathrm{LN}^{\mathrm{T}}$ were used as reference strains in determining DNA-DNA relatedness. The micro-organisms

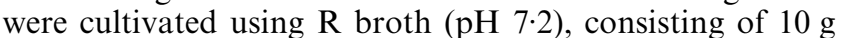
bacto peptone (Difco), $5 \mathrm{~g}$ bacto yeast extract (Difco), $5 \mathrm{~g}$ bacto malt extract (Difco), $5 \mathrm{~g}$ bacto Casamino acids (Difco), $2 \mathrm{~g}$ bacto beef extract, $2 \mathrm{~g}$ glycerol, $50 \mathrm{mg}$ Tween 80 and $1 \mathrm{~g} \mathrm{MgSO}_{4} \cdot 7 \mathrm{H}_{2} \mathrm{O}$ in 11 deionized water, with shaking (130 r.p.m.) until the late exponential phase of growth at $27^{\circ} \mathrm{C}$. Cells for analysis of fatty acids were prepared by using AT medium with $1 \%$ acetic acid and phosphate buffer $(\mathrm{pH} \mathrm{7})$ instead of $n$-tetradecane and $100 \mathrm{mM}$ $\mathrm{NaHCO}_{3} / \mathrm{Na}_{2} \mathrm{CO}_{3}$ buffer. Other culture conditions were as described above.

Phenotypic characterization. For identification of the isolate, $\mathrm{R}$ broth was used as a basal medium. Cultures were incubated at $27^{\circ} \mathrm{C}$ and characterized by the methods of Yamada \& Komagata (1972) and Barrow \& Feltham (1993) unless stated otherwise. Utilization of carbohydrates $(1 \%$, $\mathrm{w} / \mathrm{v})$, organic acids $(1 \%, \mathrm{w} / \mathrm{v})$, amino acids $(0.5 \%, \mathrm{w} / \mathrm{v})$ and hydrocarbons $(1 \%, \mathrm{v} / \mathrm{v})$ was tested using AT medium without $n$-tetradecane and with phosphate buffer $(\mathrm{pH} 7)$ instead of $100 \mathrm{mM} \mathrm{NaHCO} 3 / \mathrm{Na}_{2} \mathrm{CO}_{3}$ buffer. Hydrolysis of lipids was estimated using a medium containing $5 \mathrm{~g}$ polypeptone (Nihon Pharmaceutical), $3 \mathrm{~g}$ yeast extract (Kyokuto), $10 \mathrm{ml}$ tributyrin and $15 \mathrm{~g}$ agar in 11 deionized water. When hydrocarbons were not used as the substrate, cultures were incubated at $27^{\circ} \mathrm{C}$ for 2 weeks. Utilization of hydrocarbons was estimated at $5^{\circ} \mathrm{C}$ for 2 months. Tributyrin was sterilized separately and emulsified in the medium. The requirement for and tolerance of $\mathrm{NaCl}$ were determined using a medium containing $1 \mathrm{~g}$ bacto peptone, $0 \cdot 1 \mathrm{~g}$ yeast extract and 0-200 g NaCl in 11 deionized water ( $\mathrm{pH} 7 \cdot 5)$.

Electron microscopy. For observation of negatively stained cells under a transmission electron microscope (TEM), cells were grown on $\mathrm{R}$ agar ( $\mathrm{R}$ broth supplemented with $2 \%$ agar) for $3 \mathrm{~d}$, after which the cells were suspended in physiological saline solution. A small drop of the suspension was placed on a carbon-coated copper grid and the cells were negatively stained with $1 \%(\mathrm{w} / \mathrm{v})$ phosphotungstic acid and observed under a TEM (model H-800; Hitachi). For the scanning electron microscope (SEM), cells were grown on $\mathrm{R}$ agar and were immersed in a $2 \%(\mathrm{v} / \mathrm{v})$ glutaraldehyde solution in $0 \cdot 1 \mathrm{M}$ cacodylate buffer $(\mathrm{pH} 7 \cdot 0)$ for $2 \mathrm{~h}$. After washing three times with $0 \cdot 1 \mathrm{M}$ cacodylate buffer, cells were fixed in $1 \%(\mathrm{w} / \mathrm{v}) \mathrm{OsO}_{4}$ for $2 \mathrm{~h}$, dehydrated in a graduated ethanol series $(50-100 \%, \mathrm{v} / \mathrm{v})$ and substituted with amyl acetate. Preparations were dried to a critical point in $\mathrm{CO}_{2}$, fixed on a specimen mount and sputter-coated with platinum and palladium. The specimen were observed under an SEM (model S-4000; Hitachi) at $3 \cdot 0 \mathrm{kV}$.

Chemotaxonomic characterization. Analyses of cellular fatty acids and isoprenoid quinones were performed as described previously (Yumoto et al., 1998). Trimethylsilylated derivatives of mycolic acids were analysed as described by Rainey et al. (1995b). The meso-diaminopimelic acid in the cell wall was identified by TLC (art. no. 5552, DC-Alufoline cellulose; Merck) as described by Yamada \& Komagata (1970). The glycolate test was performed based on the method of Uchida \& Aida (1977)

DNA base composition and DNA-DNA hybridization. Bacterial DNA was prepared according to the method of Marmur (1961). The DNA obtained was digested with nuclease P1 (Yamasa Shoyu) and the resulting nucleotides were separated by HPLC (Tamaoka \& Komagata, 1984). The level of DNA-DNA relatedness was determined fluorometrically by the method of Ezaki et al. (1989) using photobiotin-labelled DNA probes and black microplates.

16S rRNA gene sequencing. The $16 \mathrm{~S}$ rRNA gene sequence corresponding to positions $27-1519$ in the 16S rRNA gene sequence of Escherichia coli (Brosius et al., 1978) was amplified by PCR. The $1 \cdot 5-\mathrm{kb}$ PCR product was sequenced directly by the dideoxynucleotide chain-termination method using a DNA sequencer (PRISM 377; Applied Biosystems). Multiple alignments of the sequence were performed and the nucleotide substitution rate $\left(K_{\text {nuc }}\right.$ value) was calculated. A phylogenetic tree was constructed by the neighbour-joining method (Kimura, 1980; Saitou \& Nei, 1987) using the CLUSTAL W program (Thompson et al., 1994). Similarity values for sequences were calculated using the GENETYX computer program (Software Development).

\section{RESULTS AND DISCUSSION}

\section{Morphology}

Colonies of strain ILA- $1^{\mathrm{T}}$ on $\mathrm{R}$ agar were circular, convex, entire, opaque and coral red. Cells were Grampositive, non-motile, non-spore-forming rods, $0 \cdot 8-1 \cdot 0$ by $1 \cdot 0-2 \cdot 2 \mu \mathrm{m}$ in size (Fig. 1). Cells exhibited a snapping-type division.

\section{Phenotypic characteristics}

Strain ILA- $1^{\mathrm{T}}$ exhibited the following phenotypic characteristics. Catalase and oxidase reactions were positive. The strain was negative for reduction of nitrate, $\mathrm{H}_{2} \mathrm{~S}$ production, urease, indole production, the Voges-Proskauer test and methyl red. Growth occurred between $\mathrm{pH} 7$ and 10; the optimum $\mathrm{pH}$ was $\mathrm{pH}$ 9-10 in $\mathrm{R}$ broth. The strain grew in media supplemented with $0-10 \% \mathrm{NaCl}$ but not in media with more than $12.5 \% \mathrm{NaCl}$. It grew at $5-30{ }^{\circ} \mathrm{C}$, but not at $40{ }^{\circ} \mathrm{C}$ or higher. The isolate hydrolysed lipid and Tweens 20, 40, 60 and 80, but not casein, gelatin, starch or DNA. It utilized D-glucose, pyruvate, acetate, $n$-butyrate, isobutyrate and ethanol but not D-xylose, 


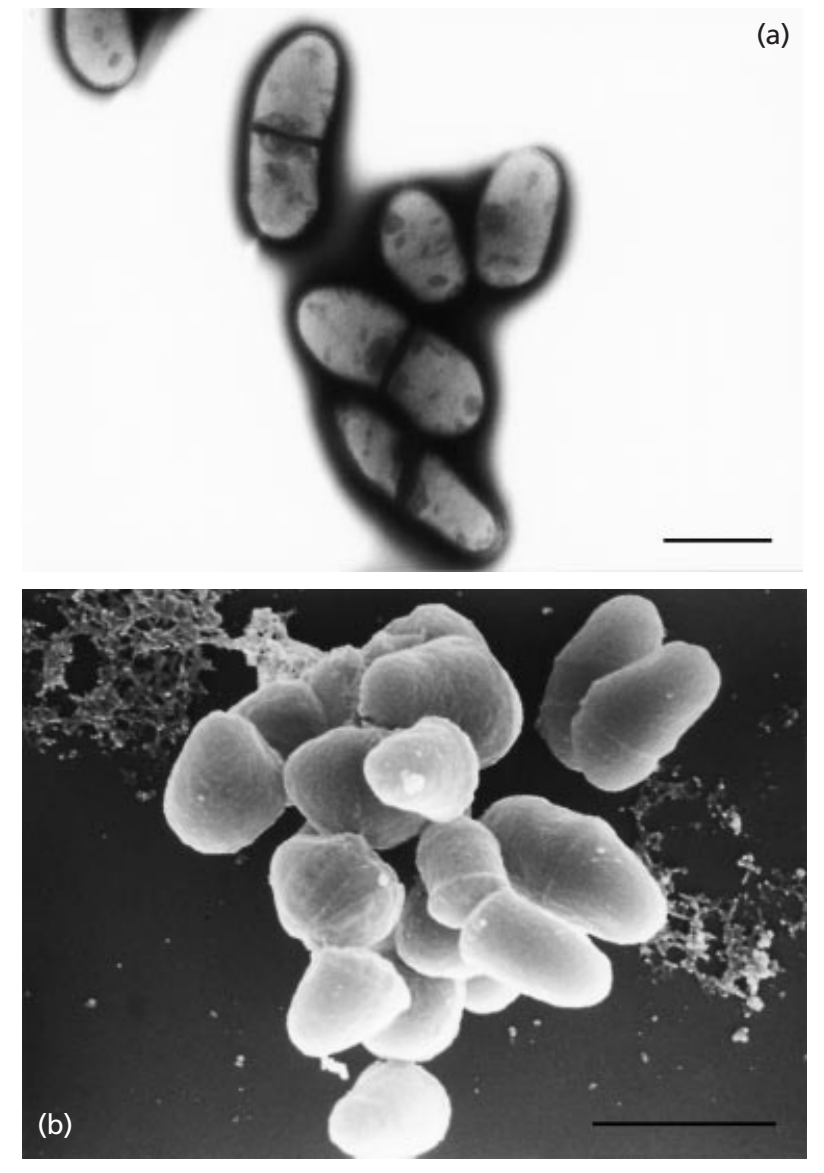

Fig. 1. (a) Transmission electron micrograph of negatively stained cells of Dietzia psychralcaliphila ILA-1 ${ }^{\top}$. The cells were grown on $\mathrm{R}$ agar for $48 \mathrm{~h}$ at $27^{\circ} \mathrm{C}$. (b) Scanning electron micrograph of cells of platinum/palladium-coated Dietzia psychralcaliphila ILA-1 ${ }^{\top}$. Bars, $1 \mu \mathrm{m}$.

D-mannose, raffinose, trehalose, D-cellobiose, lactose, gluconate, glucuronate, $\alpha$-D-galacturonate, glutarate, DL-malate, glutamate, $\alpha$-ketoglutarate, fumarate, DLglycerate, L-tartrate, L-aspartate, arabitol, aconitate, myo-erythritol, D-glycerol, $p$-hydroxybenzoate, D- $\alpha$ alanine, L-leucine, L-tyrosine, L-lysine, L-arginine, Lornithine or DL-phenylalanine. Other characteristics are described in Table 1. Utilization of hydrocarbons by strain ILA- $1^{\mathrm{T}}$ was also tested using AT medium $(\mathrm{pH} 7)$ at $5{ }^{\circ} \mathrm{C}$. It utilized $n$-tridecane, $n$-tetradecane, $n$ pentadecane, $n$-hexadecane, $n$-eicosane, $n$-tetracosane, $n$-octacosane and pristane but not $n$-dodecane, $n$ dotriacontane, cyclododecane, fluorene, anthracene or pyrene. Strain ILA- $1^{\mathrm{T}}$ utilized $n$-tetradecane over a wide $\mathrm{pH}$ range (6-10) and the optimum $\mathrm{pH}$ was 10 at $27^{\circ} \mathrm{C}$. The strain is expected to have potential for in situ bioremediation of oil-contaminated soil and water at low temperatures over a wide $\mathrm{pH}$ range.

\section{Chemotaxonomic characteristics}

GC analysis of methyl ester derivatives of cellular fatty acids of the strain revealed that the major components
Table 1. Comparison of phenotypic characteristics of Dietzia species

Taxa are identified as: 1, D. psychralcaliphila ; 2, D. maris; 3, D. natronolimnaea. Culture was performed under neutral conditions. + , Positive; -, negative; NA, not available. All strains were able to grow at $\mathrm{pH} 10$ and 7 on $\mathrm{R}$ medium. All strains were positive for utilization of acetate, D-fructose, D-glucose, propionate, 3-hydroxybutyrate and valerate and negative for utilization of D-galactose, lactose, sucrose, salicin, D-melibiose, D-sorbitol, L-arabinose, caprate, histidine, rhamnose, D-ribose, inositol, maltose, DL-lactate, L-alanine and $\mathrm{N}$-acetylglucosamine.

\begin{tabular}{|llll|}
\hline Characteristic & $\mathbf{1}$ & $\mathbf{2}^{*}$ & $\mathbf{3}^{\dagger}$ \\
\hline Utilization of: & & & \\
Glutamate & - & + & + \\
Succinate & - & - & + \\
Mannitol & - & - & + \\
Citrate & - & - & + \\
L-Proline & - & - & + \\
Reduction of nitrate & - & + & NA \\
H. & - & + & NA \\
Urease & - & + & NA \\
\hline
\end{tabular}

* Data for utilization of substrates were obtained in this study using AT medium.

$\dagger$ Data were obtained from Duckworth et al. (1998).

Table 2. Comparison of chemotaxonomic characteristics of Dietzia species

Taxa are identified as: 1, D. psychralcaliphila $; 2$, D. maris $; 3$, D. natronolimnaea. Data for D. maris were obtained in this study. All three taxa contain straight-chain saturated, monounsaturated and 10-methyl branched fatty acids, mesodiaminopimelic acid as the major peptidoglycan diamino acid and MK- $8\left(\mathrm{H}_{2}\right)$ as the major menaquinone. NA, Not available.

\begin{tabular}{|lccc|}
\hline Character & $\mathbf{1}$ & $\mathbf{2}$ & $\mathbf{3}$ \\
\hline $\begin{array}{l}N \text {-Glycolyl in glycan moiety } \\
\text { of cell wall }\end{array}$ & - & - & NA \\
$\begin{array}{l}\text { DNA G + C content (mol \%) } \\
\text { Mycolic acid chain length }\end{array}$ & $69 \cdot 6$ & $70 \cdot 4$ & $66 \cdot 1$ \\
\hline
\end{tabular}

were $\mathrm{C}_{16: 0}(25 \%), \mathrm{C}_{16: 1}(18 \%), 10-\mathrm{MeC}_{18: 0}(22 \%)$ and $\mathrm{C}_{18: 1}(25 \%)$ and the minor components were $\mathrm{C}_{13: 0}$ $(2 \%), C_{17: 1}(2 \%)$ and $C_{18: 0}(2 \%)$. The amount of total unsaturated fatty acids was $45 \cdot 2 \%$. The cell wall of the strain contained meso-diaminopimelic acid, arabinose and galactose. Other characteristics are described in Table 2 .

\section{$16 S$ rRNA gene sequence analysis}

The nucleotide sequence of the 16S rRNA gene amplified enzymically from strain ILA- $1^{\mathrm{T}}$ was determined by direct automated sequencing. A total of 


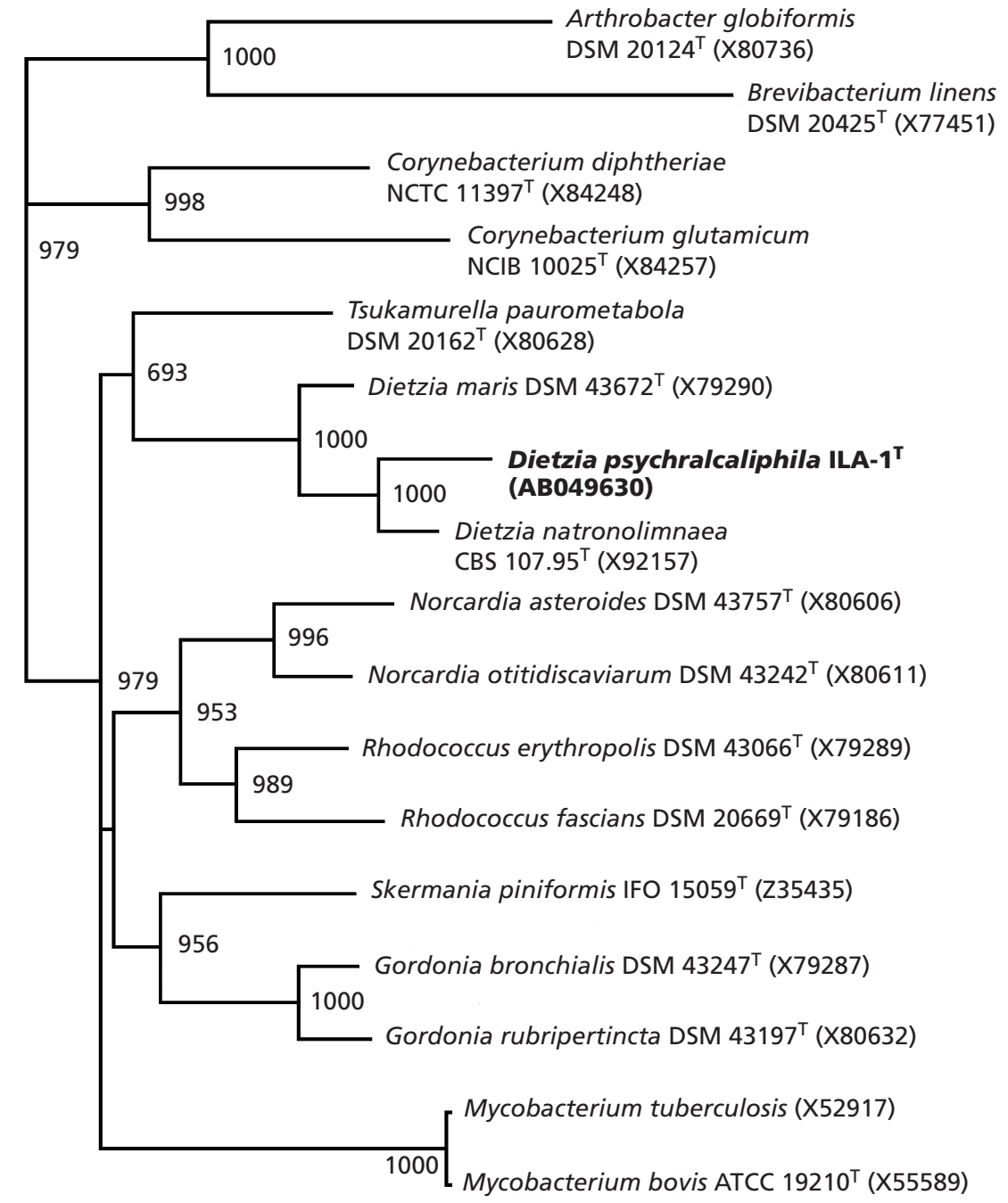

$0 \cdot 01$
Fig. 2. Phylogenetic tree of Dietzia psychralcaliphila ILA-1 ${ }^{\top}$ and reference organisms derived from 16S rRNA gene sequence data using theneighbour-joining method. Numbers indicate bootstrap values greater than 500 . Bar, $0.01 K_{\text {nuc }}$ unit.
1483 nucleotides was sequenced and the primary structure was aligned with those of 16 representative members of wall chemotype IV (taxa containing mesodiaminopimelic acid, arabinose and galactose; Lechevalier \& Lechevalier, 1970), which contain mycolic acids, and other related organisms. A phylogenetic tree was constructed on the basis of the distance matrix data (Fig. 2). It showed that strain ILA-1 ${ }^{\text {T }}$ formed a coherent cluster with species of the genus Dietzia. The genus contained only two species, $D$. maris and $D$. natronolimnaea. The degrees of sequence similarity of strain ILA- $1^{\mathrm{T}}$ to $D$. maris and $D$. natronolimnaea were respectively $96 \cdot 1$ and $96 \cdot 8 \%$.

\section{DNA base composition and DNA-DNA hybridization}

The DNA $\mathrm{G}+\mathrm{C}$ content of strain ILA-1 ${ }^{\mathrm{T}}$ was $69.6 \mathrm{~mol} \%$. According to the results of $16 \mathrm{~S}$ rRNA gene sequence analysis, strain ILA $-1^{\mathrm{T}}$ is included in the genus Dietzia. The levels of DNA-DNA relatedness of strain ILA- $1^{\mathrm{T}}$ to D. maris and D. natronolimnaea were determined to be 38.4 and $49.7 \%$, respectively.

\section{Distribution of Dietzia strains}

Dietzia strains have been isolated from soil, skin and intestinal tracts of the carp (Nesterenko et al., 1982; Rainey et al., 1995b), deep-sea sediments (Colquhoun et al., 1998), the deepest sea mud of the Mariana Trench (Takami et al., 1997) and soda lakes (Jones et al., 1998; Duckworth et al., 1998). Furthermore, Dietzia strains are able to grow at alkaline as well as neutral $\mathrm{pH}$. These results suggest that Dietzia strains are distributed widely in nature and a still wider distribution is expected. In the present study, strain ILA- ${ }^{\mathrm{T}}$ was isolated from a drain pool of a fish-eggprocessing plant. Several kinds of marine fish are processed in this plant. This suggests that Dietzia strains may exist in the skin or intestinal tracts of marine fish. However, further studies are needed to clarify this. 


\section{Conclusions}

Although strain ILA- $1^{\mathrm{T}}$ did not show significantly high levels of DNA-DNA relatedness to D. maris and $D$. natronolimnaea, the strain was difficult to discriminate from the two species of the genus Dietzia on the basis of physiological and biochemical characteristics (Table 1) and chemotaxonomic properties (Table 2). This observation is in accordance with a report that physiological and biochemical characteristics and chemotaxonomic properties are not particularly discriminatory for mycolic acid-containing bacteria (Rainey et al., 1995a). Based on physiological and biochemical characteristics, the phylogenetic position as determined by $16 \mathrm{~S}$ rRNA gene analysis and DNA-DNA relatedness, the name Dietzia psychralcaliphila sp. nov. is proposed for this novel organism.

\section{Description of Dietzia psychralcaliphila sp. nov.}

Dietzia psychralcaliphila (psy.chral.ca.li.phil'a. Gr. adj. psychros cold; N.L. alcali alkali, from Arabic al qali potash soil; Gr. adj. philos friendly to; N.L. fem. adj. psychralcaliphila loving cold, alkaline environments).

Cells are Gram-positive, non-motile, non-sporeforming rods $(0 \cdot 8-1 \cdot 0$ by $1 \cdot 0-2 \cdot 2 \mu \mathrm{m})$. Cells show a snapping-type division. Colonies are circular, convex, glistening and coral red. Catalase and oxidase reactions are positive. Negative for reduction of nitrate, $\mathrm{H}_{2} \mathrm{~S}$ production, urease, indole production, the Voges-Proskauer test and methyl red. Growth occurs between $\mathrm{pH} 7$ and 10 in $\mathrm{R}$ broth. Grows in media supplemented with $0-10 \% \mathrm{NaCl}$ but not in media with salinity higher than $12 \cdot 5 \%$. Grows at $5-30{ }^{\circ} \mathrm{C}$, but not at $40{ }^{\circ} \mathrm{C}$ or higher. The major isoprenoid quinone is MK-8 $\left(\mathrm{H}_{2}\right)$. The whole-cell fatty acids consist of $\mathrm{C}_{16: 0}$, $\mathrm{C}_{16: 1}, \mathrm{C}_{18: 1}$ and $10-\mathrm{MeC}_{18: 0}$ as tuberculostearic acid. Short-chain mycolic acids are present (34-39 carbon atoms). The cell wall contains meso-diaminopimelic acid, arabinose and galactose; the glycan moiety of the cell wall contains acetyl residues. The isolate hydrolyses lipid and Tweens 20, 40, 60 and 80, but not casein, gelatin, starch or DNA. Utilizes D-glucose, D-fructose, propionate, valerate, 3-hydroxybutyrate, pyruvate, acetate, $n$-butyrate, isobutyrate, ethanol, $n$-tridecane, $n$-pentadecane, $n$-hexadecane, $n$-eicosane, $n$-tetracosane and pristane but not D-xylose, D-arabinose, D-mannose, D-galactose, raffinose, sucrose, trehalose, D-cellobiose, melibiose, lactose, maltose, D-ribose, rhamnose, salicin, gluconate, glucuronate, $\alpha$-D-galacturonate, glutarate, DL-malate, DL-lactate, citrate, glutamate, $\alpha$-ketoglutarate, succinate, fumarate, DLglycerate, caprate, L-tartrate, L-aspartate, arabitol, aconitate, mannitol, D-sorbitol, inositol, myo-erythritol, D-glycerol, $p$-hydroxybenzoate, L- $\alpha$-alanine, $\mathrm{D}-\alpha$-alanine, L-leucine, histidine, L-proline, L-tyrosine, L-lysine, L-arginine, L-ornithine, DL-phenylalanine, $\mathrm{N}$ acetylglucosamine, $n$-decane, $n$-dotriacontane, cyclododecane, fluorene, anthracene or pyrene. The DNA $\mathrm{G}+\mathrm{C}$ content is $69.6 \mathrm{~mol} \%$ (determined by HPLC).
The type strain, ILA- $1^{\mathrm{T}}$, has been deposited at The Institute of Physical and Chemical Research (RIKEN), Wako, Japan, as JCM $10987^{\mathrm{T}}$, at the IAM Culture Collection, The University of Tokyo, Tokyo, Japan, as IAM $14896^{\mathrm{T}}$ and at the National Collection of Industrial and Marine Bacteria, Aberdeen, UK, as NCIMB $13777^{\mathrm{T}}$.

\section{ACKNOWLEDGEMENTS}

The authors would like to thank Dr W. D. Grant (University of Leicester) and Dr B.E. Jones (Genencor International) for providing $D$. natronolimnaea $15 \mathrm{LN} 1^{\mathrm{T}}$.

\section{REFERENCES}

Barrow, G. I. \& Feltham, R. K. A. (editors) (1993). Cowan and Steel's Manual for the Identification of Medical Bacteria, 3rd edn. Cambridge: Cambridge University Press.

Brosius, J., Palmer, M. L., Kennedy, P. J. \& Noller, H. F. (1978). Complete nucleotide sequence of a $16 \mathrm{~S}$ ribosomal RNA gene from Escherichia coli. Proc Natl Acad Sci U S A 75, 4801-4805.

Colquhoun, J. A., Heald, S. C., Li, L., Tamaoka, J., Kato, C., Horikoshi, K. \& Bull, A. T. (1998). Taxonomy and biotransformation activities of some deep-sea actinomycetes. Extremophiles 2, 269-277.

Duckworth, A. W., Grant, S., Grant, W. D., Jones, B. E. \& Meijer, D. (1998). Dietzia natronolimnaios sp. nov., a new member of the genus Dietzia isolated from an East African soda lake. Extremophiles 2, 359-366.

Ezaki, T., Hashimoto, Y. \& Yabuuchi, E. (1989). Fluorometric deoxyribonucleic acid-deoxyribonucleic acid hybridization in microdilution wells as an alternative to membrane filter hybridization in which radioisotopes are used to determine genetic relatedness among bacterial strains. Int J Syst Bacteriol 39, 224-229.

Foght, J., Semple, K., Gauthier, C., Westlake, D. W. S., Blenkinsopp, S., Sergy, G., Wang, Z. \& Fingas, M. (1999). Effect of nitrogen source on biodegradation of crude oil by a defined bacterial consortium incubated under cold, marine conditions. Environ Technol 20, 839-849.

Jones, B. E., Grant, W. D., Duckworth, A. W. \& Owenson, G. G. (1998). Microbial diversity of soda lakes. Extremophiles 2, 191-200.

Kimura, M. (1980). A simple method for estimating evolutionary rates of base substitutions through comparative studies of nucleotide sequences. J Mol Evol 16, 111-120.

Lechevalier, M. P. \& Lechevalier, H. (1970). Chemical composition as a criterion in the classification of aerobic actinomycetes. Int $J$ Syst Bacteriol 20, 435-443.

MacCormack, W. P. \& Fraile, E. (1997). Characterization of a hydrocarbon degrading psychrophilic Antarctic bacterium. Antarctic Sci 9, 150-155.

Margesin, R. \& Schinner, F. (1997a). Bioremediation of diesel-oilcontaminated alpine soils at low temperatures. Appl Microbiol Biotechnol 47, 462-468.

Margesin, R. \& Schinner, F. (1997b). Efficiency of indigenous and inoculated cold-adapted soil microorganisms for biodegradation of diesel oil in alpine soils. Appl Environ Microbiol 63, 2660-2664.

Margesin, R. \& Schinner, F. (1997c). Laboratory bioremediation experiments with soil from a diesel-oil contaminated site 
- significant role of cold-adapted microorganisms and fertilizers. J Chem Technol Biotechnol 70, 92-98.

Margesin, R. \& Schinner, F. (1999). Biological decontamination of oil spills in cold environments. J Chem Technol Biotechnol 74, 381-389.

Marmur, J. (1961). A procedure for the isolation of deoxyribonucleic acid from micro-organisms. J Mol Biol 3, 208-218.

Nesterenko, O. A., Nogina, T. M., Kasumova, S. A., Kvasnikov, E. I. \& Batrakov, S. G. (1982). Rhodococcus luteus nom. nov. and Rhodococcus maris nom. nov. Int J Syst Bacteriol 32, 1-14.

Rainey, F. A., Burghardt, J., Kroppenstedt, R. M., Klatte, S. \& Stackebrandt, E. (1995a). Phylogenetic analysis of the genera Rhodococcus and Nocardia and evidence for the evolutionary origin of the genus Nocardia from within the radiation of Rhodococcus species. Microbiology 141, 523-528.

Rainey, F. A., Klatte, S., Kroppenstedt, R. M. \& Stackebrandt, E. (1995b). Dietzia, a new genus including Dietzia maris comb. nov., formerly Rhodococcus maris. Int J Syst Bacteriol 45, $32-36$

Saitou, N. \& Nei, M. (1987). The neighbor-joining method: a new method for reconstructing phylogenetic trees. Mol Biol Evol 4, 406-425

Takami, H., Inoue, A., Fuji, F. \& Horikoshi, K. (1997). Microbial flora in the deepest sea mud of the Mariana Trench. FEMS Microbiol Lett 152, 279-285.

Tamaoka, J. \& Komagata, K. (1984). Determination of base composition by reversed-phase high-performance liquid chromatography. FEMS Microbiol Lett 25, 125-128.

Thompson, J. D., Higgins, D. G. \& Gibson, T. J. (1994). CLUSTAL W: improving the sensitivity of progressive multiple sequence alignment through sequence weighting, position-specific gap penalties and weight matrix choice. Nucleic Acids Res 22, 4673-4680.

Uchida, K. \& Aida, K. (1977). Acyl type of bacterial cell wall: its simple identification by colorimetric method. J Gen Appl Microbiol 23, 249-260.

Westlake, D. W. S., Jobson, A. M. \& Cook, F. D. (1978). In situ degradation of oil in a soil of the boreal region of the Northwest Territories. Can J Microbiol 24, 254-260.

Whyte, L. G., Greer, C. W. \& Inniss, W. E. (1996). Assessment of the biodegradation potential of psychrotrophic microorganisms. Can J Microbiol 42, 99-106.

Whyte, L. G., Hawari, J., Zhou, E., Bourbonnière, L., Inniss, W. E. \& Greer, C. W. (1998). Biodegradation of variable-chain-length alkanes at low temperatures by a psychrotrophic Rhodococcus sp. Appl Environ Microbiol 64, 2578-2584.

Whyte, L. G., Slagman, S. J., Pietrantonio, F., Bourbonnière, L., Koval, S. F., Lawrence, J. R., Inniss, W. E. \& Greer, C. W. (1999). Physiological adaptations involved in alkane assimilation at a low temperature by Rhodococcus sp. strain Q15. Appl Environ Microbiol 65, 2961-2968.

Yamada, K. \& Komagata, K. (1970). Taxonomic studies on coryneform bacteria. II. Principal amino acids in the cell wall and their taxonomic significance. J Gen Appl Microbiol 16, 103-113.

Yamada, K. \& Komagata, K. (1972). Taxonomic studies on coryneform bacteria. IV. Morphological, cultural, biochemical, and physiological characteristics. J Gen Appl Microbiol 18, 339-416.

Yumoto, I., Yamazaki, K., Sawabe, T., Nakano, K., Kawasaki, K., Ezura, Y. \& Shinano, H. (1998). Bacillus horti sp. nov., a new Gram-negative alkaliphilic bacillus. Int J Syst Bacteriol 48, $565-571$. 